\title{
Kristen Hopewell, Clash of Powers: US-China Rivalry in Global Trade Governance
}

\author{
(Cambridge: Cambridge University Press, 2020), xii + 249p., \$131.92 \\ hardback; $\$ 36.82$ paperback
}

\section{Amir $\operatorname{Khan}^{1} \mathbb{D}$}

Accepted: 9 August 2021 / Published online: 28 August 2021

(c) The Author(s) 2021

Trade deals do not happen in a vacuum. Many competing historical grievances and asymmetries are brought to the fore and either maintained or exacerbated. Moreover, the narratives used to discuss these deals carry embedded assumptions and unexamined biases that favor the status quo. The usual status quo, as ratified after the Bretton Woods Agreement in 1944, has the United States as uncontested leader of a new and unprecedented multilateral trading system. While many see fading US hegemony ushering in an era of a new hegemon (namely China), Kristen Hopewell offers a two-pronged retort. First, China's rise is not inevitable, it's here. China already possesses the ability to seriously disrupt US goals and undermine its position of sole supremacy. Second, Hopewell notes that China's power is, as of yet, only "structural" rather than "institutional." In short, China has "demonstrated the ability to block multilateral trade rules but not to create them" (192).

Hopewell situates her arguments against a trend in scholarship asserting that since China "benefits considerably from the existing system of global economic governance," it will ultimately "support the overarching goals and principles of the system and seek to sustain it" (p. 2). She instead asserts that the smooth integration of China into the "US-led liberal international economic order" (p. 2) is not happening as predicted. Hopewell seeks to demonstrate through the discussion of five specific cases, including the failed Doha trade talks (2001-11), that China now has the ability to "persistently block the US from achieving its objectives" (p. 8).

Hopewell sees China as destabilizing an "international regulatory regime . . . [that] has worked well for decades" (p. 157) via the China Paradox, which is "the fact that China is now both a major economic power and a developing country" (p. 29). China demands, among other things, the "SDT" (p. 38) (Special Differential Treatment) afforded developing countries, arguing that in terms of per capita GDP

Amir Khan

amirazizkhan@dlmu.edu.cn

1 School of Foreign Languages, Dalian Maritime University, 1 Linghai Rd, Dalian,

People's Republic of China 116026 
(p. 18), it still is a developing country. However, never before in recent trade history has a country afforded such status simultaneously been the global leader in merchandise exports (p. 42). Under current trade rules, then, China is demanding trade exemptions designed for countries which no longer match its growing stature. This unique historical contingency is wreaking havoc on established trade norms. Although Hopewell seems to suggest that China is intent on pressing this asymmetry for maximal gain, she insists she is not offering a "blame China" (p. 24) narrative. She would rather "take seriously China's objectives, while nonetheless critically evaluating their effects" (p. 25). Despite this assertion, she states

China is hardly unique among the major economic powers in blocking or undercutting global environmental initiatives that run counter to its economic interests. However, China's emerging environmental leadership elsewhere in global governance is undermined by its much more self-serving behavior in the trade regime, where it is obstructing reforms of the trading system that are crucial to the goal of protecting the environment and promoting sustainable development. (p. 197)

Hopewell provides no policy prescriptions to square China's "legitimate" (p. 24) policy objectives with that of the US or other nations. The reader is left to infer that since the US can no longer "bind China to more stringent trade rules" (p. 198), China exists as an uncontrollable menace among nations.

At one point, Hopewell grants that recent US pullback from multilateral trade commitments is evident of a "spilt-milk" mentality. Rather than fault Trump for recent US-China trade rows, Hopewell speculates briefly that since US influence over international trade has "diminished" (201), it makes perfect structural sense for the USA to act as bulwark to effective multilateral trade. Yet a balanced discussion that includes the role of domestic and contradictory US policies (floated by an increasingly dysfunctional Congress) on the failed Doha trade talks, for example, is lacking. By book's end, only two options remain: either China "corrects" its behavior, or a host of problems ensue, including continued environmental degradation, depletion of global fish stocks, fluctuating food prices, and continued third world poverty. Yet Hopewell does not stress emphatically enough that these problems have always been hallmarks of a Liberal world order long before China joined the WTO; the China Paradox does not fundamentally alter any of these. Hopewell misses the main lesson: the system itself requires more equitable rules to truly deliver on the promises of free trade. China did not create the conditions allowing for its own systemic advantage; rather, it took up a rational position precisely by following the rules, just as the US and a host of other nations have done in the past. If new rules are required, the US, which has benefitted for so long by exploiting systemic asymmetries in global trade, may no longer be in a position to write them. The more prescient question then is, can China, or anyone else? Hopewell registers a requisite sense of angst at the prospect; but rather than plot a way forward, she succumbs in the mean to another blame China narrative. 
Open Access This article is licensed under a Creative Commons Attribution 4.0 International License, which permits use, sharing, adaptation, distribution and reproduction in any medium or format, as long as you give appropriate credit to the original author(s) and the source, provide a link to the Creative Commons licence, and indicate if changes were made. The images or other third party material in this article are included in the article's Creative Commons licence, unless indicated otherwise in a credit line to the material. If material is not included in the article's Creative Commons licence and your intended use is not permitted by statutory regulation or exceeds the permitted use, you will need to obtain permission directly from the copyright holder. To view a copy of this licence, visit http://creativecommons.org/licen ses/by/4.0/.

Amir Khan is Xinghai Associate Professor of English in the School of Foreign Languages at Dalian Maritime University. His books include Comedies of Nihilism (2017) and Shakespeare in Hindsight (2016). He is managing editor of Conversations: The Journal of Cavellian Studies. He lives and works in China. 